\title{
波力発電適地選定のための日本沿岸における 波パワーの評価
}

\author{
片山 裕之 ${ }^{1} \cdot$ 米山 治男 $2 \cdot$ 下迫 健一郎 3 \\ 1正会員 五洋建設株式会社 技術研究所 ( $7329-2746$ 栃木県那須塩原市1534-1) \\ E-mail:Hiroyki.Katay ama@mail.penta-ocean.co.jp
}

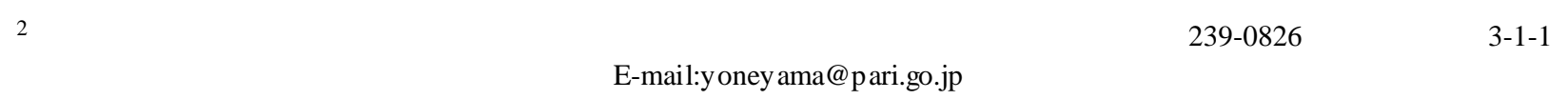

3 正会員 独立行政法人港湾空港技術研究所 海洋研究領域長 (

E-mail:shimosako@pari.go.jp

東日本大震災以後のエネルギー政策転換の機運の高まりや, 海洋基本計画において海洋再生可能エネル ギーの利用促進か諤われるなど, 自然エネルギーの期待が高くなっている. 実際に海洋再生可能エネルギ 一の検討が進んできており，現地海域での実証試験も始まっているものもある. 弚の1つである波力発電 についてもいくつかのタイプが検討されているが, 発電量算出の基礎となる波パワーの精度の高い予測が 重要となってくる.日本沿岸の波パワーについては過去にも整理されているが, 本研究では, 更に対象地 点と統計期間を増やし再整理を行い, 波パワーの海域特性を考察した . 更に波力発電導入ポテンシャルが 高い離島として大島波浮港と三宅島三池港を対象とし，設置を想定した防波堤位置の波パワーを試算した。

Key Words : Wave Power, Wave Energy, NOWPHAS, GPV, Wave Power Converter

\section{1. はじめに}

東日本大震災以後のエネルギー政策転換の機運の高ま りや, 海洋基本計画において海洋再生可能エネルギーの 利用促進力謳われるなど，自然エネルギーへの期待が高 くなっている．また実際にも風力，波力，潮流などを利 用した海洋再生可能エネルギーの検討が進んできており， 現地海域で実証試験が始まっているものもある，弚の

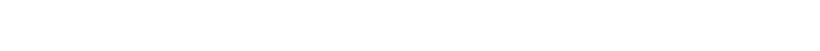
されているが, 発電量算出の基礎となる波パワーの精度 の高い予測が重要となってくる.日本全国の波パワーに ついては過去に検討されているが訪A，弚の後の波浪観 測データも蓄積されていることや, 最近ではGPVデータ に代表される波浪推算データを利用した整理も行われて いる吅。

本研究ては, 先ず過去に整理された沿岸の波パワー分 布 ${ }^{334}$ を，更に対象地点と統計期間を増やし再整理を行 い, 波パワーの海域特性を考察した . 更に波力発電導入 ポテンシャルが高いと考えられている離島として大島と 三宅島を対象に波パワーの試算を行った .

\section{2. 全国沿岸の波パワーの整理}

(1) NOWPHASデータによる日本全国沿岸の波パワー

波力発電の適地選定にあたっては, 先ず発電ポテンシ ヤルの評価に必要な波パワーの分布が重要となる.日本 沿岸の波パワーについては，例えは高橋ら ${ }^{23}$, 永井ら により整理されてはいるが，10年以上か経過しているこ とと，例えば全国港湾海洋波浪情報網(NOUPHAS, 港湾 局) 例えばのわのような全国の波浪観測網の整備が進んでき たことから，ここでは検討地点およひ統計年数を追加し 再整理を行った。なお，ここでいう波パワーとは波エネ ルギーの輸送率であり，2時間毎の有義波高と有義波周 期を用い, 次式で評価した。

$$
W P=0.5 H_{1 / 3}^{2} T_{1 / 3}
$$

ここで，WP : 波パワー $(\mathrm{kW} / \mathrm{m}), H_{1 / 3}$ : 有義波高 $(\mathrm{m})$, $T_{1 / 3}$ : 有義波周期(s)である.

NONPHAS観測網のうち, 外洋に面した水深200単以上の観 測地点のうち，一部を除き1991年から2011年までの21年 間のデータが使える地点を対象に, 波パワーの平均值だ けでなく月別平均值および年平均值の経年変化について 再整理した . 先ず，年間平均の波パワーの結果を図-1お 


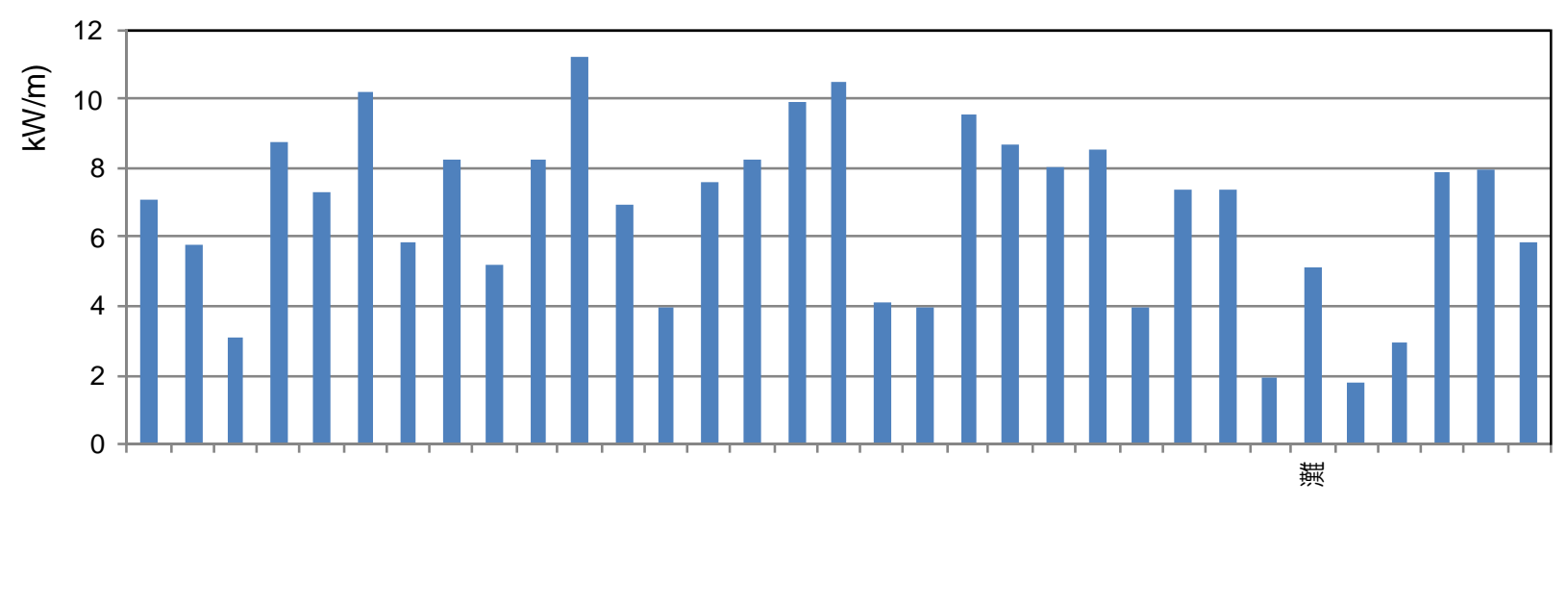

图-1 NOMPHASデータによる全国の年間平均波パワー

表-1 NOMPHASデータによる全国の平均波パワ一值一覧

\begin{tabular}{|c|c|c|c|c|c|c|c|c|c|c|c|c|c|}
\hline & 1月 & 2月 & 3月 & 4月 & 5月 & 6月 & 7月 & 8月 & 9月 & 10月 & 11月 & 12月 & 年平均 \\
\hline 留萌 & 13.3 & 11.3 & 10.0 & 4.0 & 1.8 & 0.9 & 0.8 & 1.0 & 3.2 & 7.9 & 14.7 & 16.2 & 7.1 \\
\hline 十勝 & 6.3 & 4.3 & 7.0 & 7.2 & 6.3 & 4.3 & 4.8 & 4.9 & 6.5 & 7.1 & 5.5 & 5.0 & 5.8 \\
\hline 苫小牧 & 2.5 & 2.1 & 3.0 & 3.6 & 4.0 & 2.9 & 2.7 & 3.1 & 4.9 & 3.8 & 3.0 & 2.3 & 3.1 \\
\hline 澜棚 & 18.2 & 16.2 & 13.7 & 5.0 & 2.1 & 0.9 & 1.1 & 1.2 & 3.5 & 8.6 & 16.4 & 19.6 & 8.8 \\
\hline 水川原 & 8.7 & 8.9 & 8.6 & 8.8 & 7.4 & 5.9 & 4.8 & 5.5 & 8.7 & 8.2 & 5.7 & 6.5 & 7.3 \\
\hline 深浦 & 23.7 & 19.8 & 14.1 & 5.4 & 2.4 & 1.1 & 1.5 & 1.5 & 3.4 & 7.9 & 17.2 & 24.7 & 10.2 \\
\hline 八戸 & 8.0 & 7.2 & 7.7 & 7.2 & 5.1 & 4.2 & 3.1 & 3.6 & \begin{tabular}{ll|}
.9 \\
\end{tabular} & \begin{tabular}{c|c|}
6.6 \\
\end{tabular} & 4.7 & 6.2 & 5.9 \\
\hline 久慈 & 11.2 & 8.2 & 10.0 & 10.3 & 7.6 & 5.7 & 5.5 & 6.1 & 9.0 & 9.9 & 7.0 & 8.9 & 8.2 \\
\hline 釜石 & 7.0 & 7.6 & 7.6 & 5.7 & 4.1 & 3.5 & 2.6 & 3.3 & $\begin{array}{ll}5.7 \\
\end{array}$ & $\begin{array}{ll}6.7 \\
\end{array}$ & $\begin{array}{l}3.8 \\
\end{array}$ & 5.0 & 5.2 \\
\hline 秋田 & 18.7 & 14.2 & 10.9 & \begin{tabular}{ll|}
6.0 \\
\end{tabular} & 2.7 & 1.4 & 2.2 & 1.8 & 3.2 & 6.4 & 13.4 & 20.0 & 8.2 \\
\hline 酒田 & 27.6 & 21.7 & 13.1 & 6.0 & 2.4 & 1.3 & 1.7 & 1.9 & 4.0 & 7.7 & 17.8 & 28.0 & 11.2 \\
\hline 新渇沖 & 18.1 & 15.0 & 8.4 & 28 & 1.3 & 0.6 & 0.7 & $\begin{array}{l}0.8 \\
\end{array}$ & 2.6 & \begin{tabular}{l|l|}
4.6 \\
\end{tabular} & 10.0 & 17.8 & 6.9 \\
\hline 仙台新港 & 3.1 & 2.8 & 4.2 & 4.8 & 4.3 & 2.9 & 3.6 & 3.7 & 6.3 & 5.0 & 3.9 & 2.9 & 4.0 \\
\hline 小名浜 & 7.5 & \begin{tabular}{ll|}
.6 \\
\end{tabular} & 9.8 & $\begin{array}{l}9.2 \\
\end{array}$ & 6.7 & 4.6 & 5.0 & 5.7 & 11.5 & 9.6 & 7.2 & 6.5 & 7.6 \\
\hline 常陸那阿 & 9.6 & 9.8 & 10.7 & 10.2 & 6.9 & 5.3 & 4.4 & 4.8 & 10.6 & 11.0 & 7.9 & 7.3 & 8.2 \\
\hline 鹿島 & 12.5 & 12.9 & 14.5 & 11.2 & 6.9 & 4.7 & 5.0 & 5.7 & 12.7 & 13.4 & 10.1 & 9.8 & 9.9 \\
\hline 波浮 & 11.4 & 11.4 & 12.9 & 10.9 & 8.8 & 6.8 & 8.2 & 8.6 & 13.7 & 11.7 & 10.2 & 11.3 & 10.5 \\
\hline 下田 & 3.9 & 4.3 & 4.8 & 4.1 & 3.3 & 3.3 & 4.2 & 4.1 & 5.7 & 4.1 & 3.7 & 3.6 & 4.1 \\
\hline 御前崎 & 2.3 & 2.6 & 3.5 & 3.6 & 3.1 & 3.1 & 5.5 & 6.4 & 7.6 & 4.8 & 3.6 & 2.2 & 4.0 \\
\hline 輪島 & 24.9 & 19.8 & 10.4 & 4.7 & 2.2 & 1.1 & 1.3 & 1.6 & 4.0 & 7.0 & 13.5 & 22.5 & 9.5 \\
\hline 金沢 & 24.3 & 16.7 & 8.6 & 4.2 & 1.7 & 1.2 & 1.3 & 1.5 & 2.7 & 5.9 & 12.8 & 22.9 & 8.7 \\
\hline 福井 & 19.9 & 15.8 & 8.2 & 4.2 & 1.9 & 1.0 & 1.0 & 1.2 & 2.9 & 5.2 & 11.8 & 21.4 & 8.0 \\
\hline 渒岬 & 4.9 & 5.6 & 7.1 & 7.0 & 6.5 & 7.2 & 12.0 & 16.2 & 16.7 & 8.8 & 6.6 & 5.0 & 8.5 \\
\hline 室津 & 2.2 & 2.7 & 3.1 & 3.0 & 2.7 & 3.7 & 6.5 & 7.6 & 7.5 & $\begin{array}{l}3.7 \\
\end{array}$ & 2.7 & 2.2 & 4.0 \\
\hline 鳥取 & 17.8 & 15.1 & 7.9 & 4.0 & 2.1 & 1.4 & 1.2 & 1.4 & 4.8 & 6.4 & 9.7 & 16.8 & 7.4 \\
\hline 浜田 & 16.8 & 13.3 & 8.9 & 5.0 & 2.4 & 1.7 & 1.7 & 2.1 & 5.1 & 6.2 & 9.5 & 15.4 & 7.4 \\
\hline 藍島 & 4.2 & 3.3 & 2.5 & 15 & 0.9 & 0.5 & 0.6 & 0.8 & 1.5 & 16 & 2.4 & 3.8 & 2.0 \\
\hline 玄果媇 & 9.4 & 8.4 & 6.5 & 4.0 & 2.4 & 1.7 & 1.6 & 2.5 & 5.8 & 5.1 & 6.1 & 8.4 & 5.2 \\
\hline 伊王島 & 2.1 & 2.0 & 1.7 & 13 & 0.9 & 1.9 & 3.3 & 2.8 & 2.1 & \begin{tabular}{l|l}
0.7 \\
\end{tabular} & 1.2 & 1.9 & 18 \\
\hline 志布志湾 & 0.8 & 1.1 & 1.6 & 19 & 2.0 & 2.6 & 4.6 & 7.9 & 6.1 & 3.0 & 2.3 & 1.1 & 29 \\
\hline 名瀬 & 15.3 & 12.9 & 10.1 & 5.1 & 3.0 & 3.1 & 2.7 & 4.5 & 6.8 & 7.7 & 9.6 & 14.2 & 7.9 \\
\hline 中城湾 & 4.1 & 4.2 & 4.7 & 4.4 & 4.9 & 4.4 & 10.3 & 13.9 & 14.1 & 12.6 & 11.5 & 7.1 & 8.0 \\
\hline 那覇 & 11.8 & 9.7 & 6.8 & 3.3 & 1.8 & 1.9 & 2.4 & 3.4 & 5.9 & 6.7 & 8.2 & 10.8 & 5.9 \\
\hline
\end{tabular}

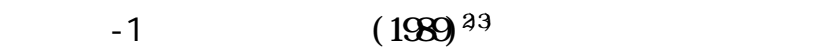
波パワ一值（約 $7 \mathrm{kWm}$ ) より大きく $8 \mathrm{~kW} / \mathrm{m}$ 超える地点は 瀬棚, 深浦, 久慈, 秋田, 酒田, 常陸那珂, 鹿島, 波浮,

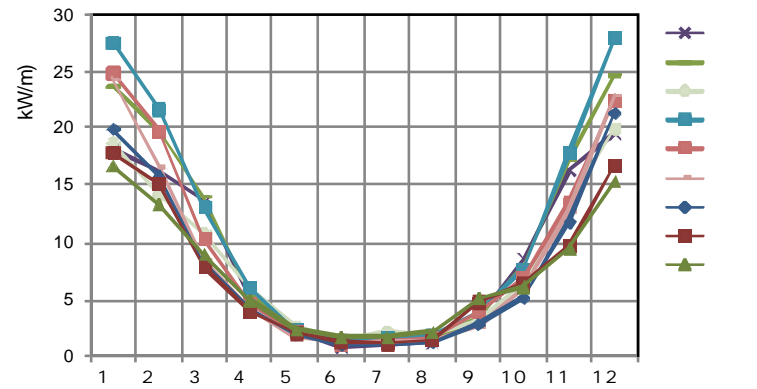

(1) 日本海側

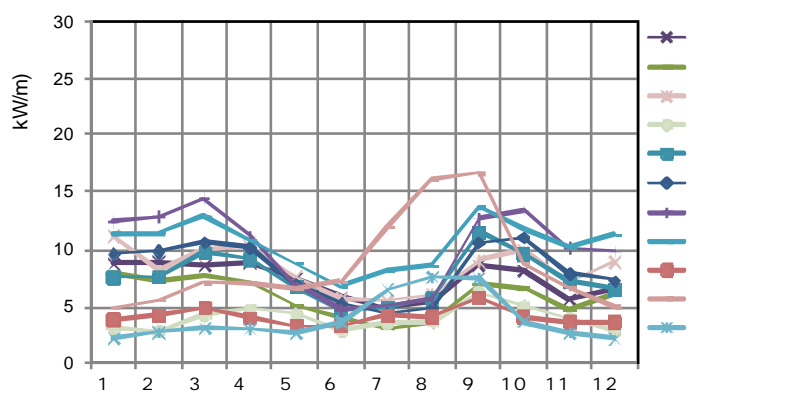

(2) 太平洋側

図-2 月別の波パワーの比較

輪島，金沢，福井，潮岬の12地点であった．

次に, 代表的な地点の波パワーの月別変化を整理した (図-2) .これをみると，日本海側では冬に20kWm m超 えるが, 夏には2kWWW下と非常に小さくなる . 一方, 太平洋側では冬場でも15kWnh下となる地点が多いが， 夏場でも5kWhW下には減少しない地点が多い. 永井ら ${ }^{4}$ は，日本海側では冬季に高波浪が夏季に低波浪力継続す ること，太平洋側では遠方から来襲するうねりの影響で 極端な低波浪が見られないとしているが，ここでも同樣 の傾向であった . 年間を通しての安定した電源提供の観 


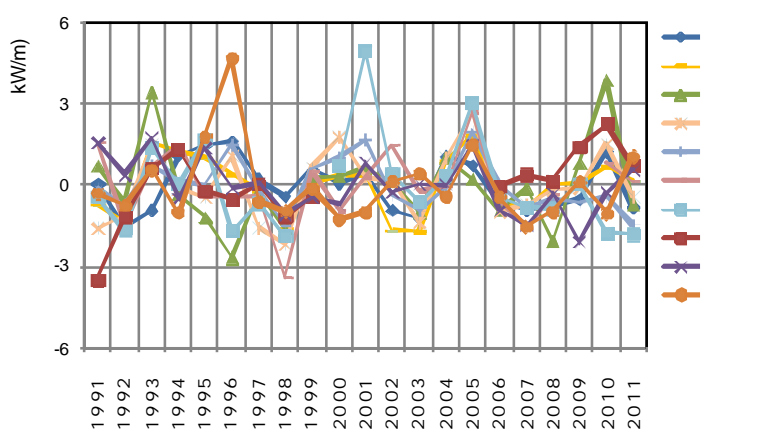

(1) 日本海側

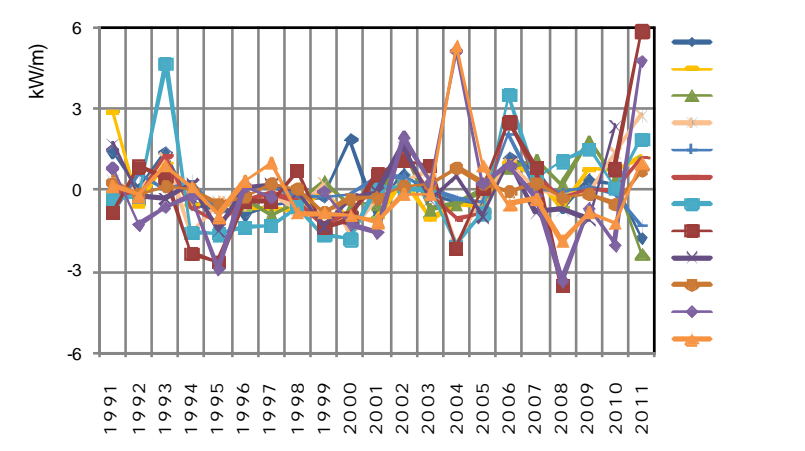

(2) 太平洋側

图-3 波パワーの経年変化の比較

点からは太平洋側の適応性が高いと言える．

図-ろには，代表的な地点について各年の平均波パワー の経年変化を整理した . 日本海側, 太平洋側とも全体的 に，平均值に対して $3 k W n$ 程度のばらつきが見られ， 波力発電実用化の際にはこの程度のばらつきが伴うこと を考慮する必要がある。

(2) NOPPHSと 『Vデータによる波パワーの比較

観測值がない海域の波パワーを評価する方法としては， 近隣の観測值から適切な換算係数などを用いて対象地点 の波浪を評価する方法か，近隣の観測值の代わりに データに代表される波浪推算データを利用する方法が考 えられる . 後者は , データの蓄積も増えてきていること や平面的な情報が得られることから，例えばNEDOははGV データを用いて全国の波パワーを推定している．ただし 統計期間か短いことや，観測値に基ついて算出した波パ ワ一值との比較，検証は行われていない，乥こで, 今後 の参考とするため、NOWHAS地点のうち比較的地形の影 響を受けない外洋の観測点 (留萌, 瀬棚, 深浦, 酒田、 新潟冲, 輪島、鳥取、浜田、むつ小川原, 久慈, 釜石, 常陸那珂, 鹿島, 波浮, 潮岬, 室津) と最も近(波浪推 算点と波パワーの比較を行った .

先ず，GVデータのうち沿岸波浪数值予測モデルGV （CWM）（領域：北緯20度～50度，東経120度～150度，

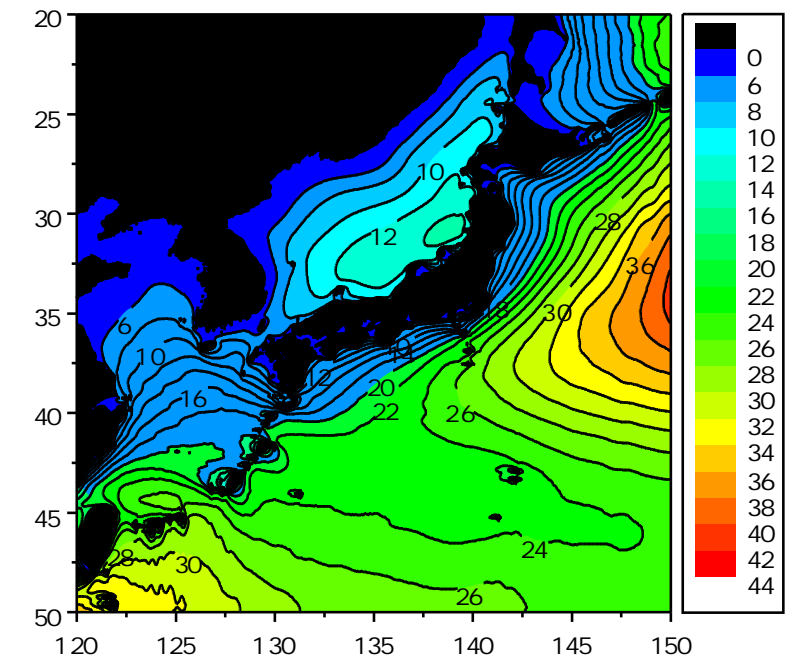

图-4 UWF゙ータから求めた波パワー分布

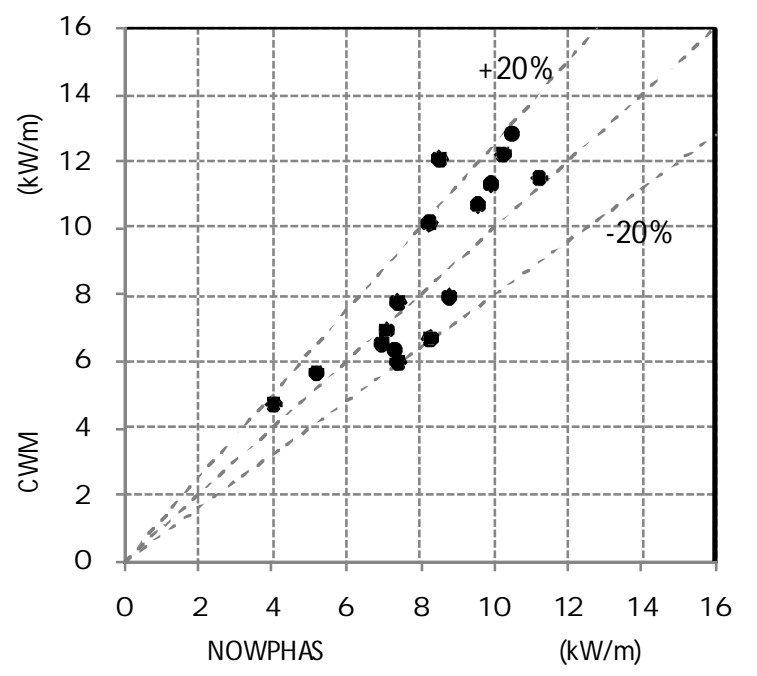

図- 5 NOWPHSとロWXら求めた波パワーの比較

空間分解能: 等緯度 等経度 0.05 度 $\times 0.05$ 度) 02008 年1 月1日から2013年12月31日までの計6年間のデータを用い て日本周辺の平面的な平均波パワーを算出した（図-4) . これをみると, 日本海側では北海道から山陰まで広い範 囲に8kWnh上上となるエリアが見られるが，太平洋側の 方が全体的にポテンシャルとしては高く，例えば東京都 島嶼部では20kWm超える高い波パワーが得られる可能 性がある。

次に，先に示したNOPPHS観測点における波パワーと， 最も近いグリッド位置のCWだータから求めた波パワー を比較した結果を図 5に示した . 図中に示したように、 全ての地点ではないが大よ关 20 \%程度の範囲に分布し ており両者の相関は比較的高い . 今後, 季節変化等も確 認する必要があるが, 波浪観測データのない海域の波パ ワー推定において, 波浪推算データを用いる場合の精度 が確忍された . 


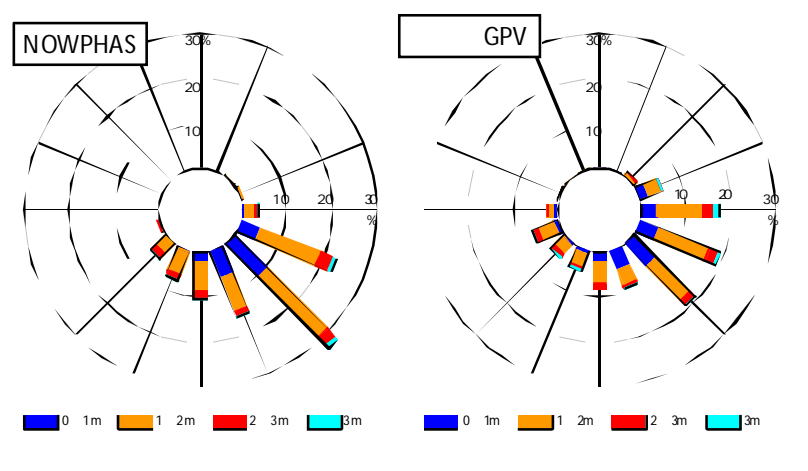

図-6 波浮港沖の波浪特性

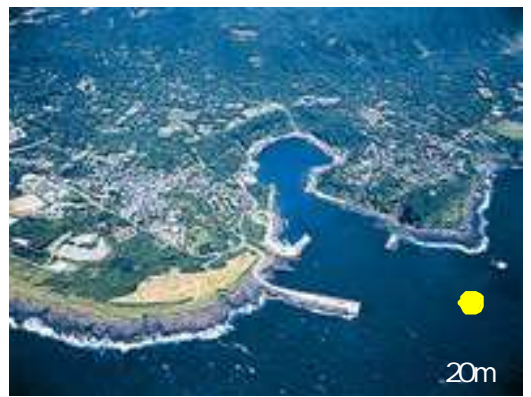

写真-1 波浮港の対象位置

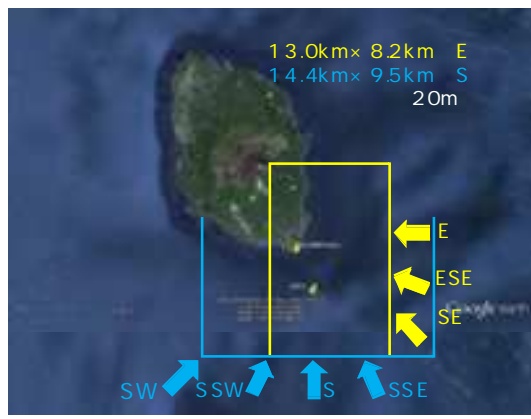

図-7 波浮港沖の波浪変形計算範囲

\section{3. 離島の波パワ一試算}

波力発電ポテンシャルの高い離島の波パワーを評価す るために波浪観測データか必要だが，上述したように波 浪観測網は必ずしも十分ではなく波浪推算データによる 補間が必要になる．本研究では，波パワーか期待できる 離島への波力発電導入を想定し, 大島波浮港および三宅 島三池港の防波堤位置に発電設備を設置した場合の波パ ワーの推定を試みた .

\section{（1） 大島波浮港の波パワ一試算}

先ず，波浮港沖についてはNOMPHAS観測データがある ことから，観測データ (水深48m) と沖合の 出現特性を比較した（図-6)．両者を比較すると，来襲 波向範囲はほぼ同じであるが，観測值は屈折により波向 SE八集中している樣子がわかる .

波浮港沖では観測値を用い, 沖合から防波堤部までの

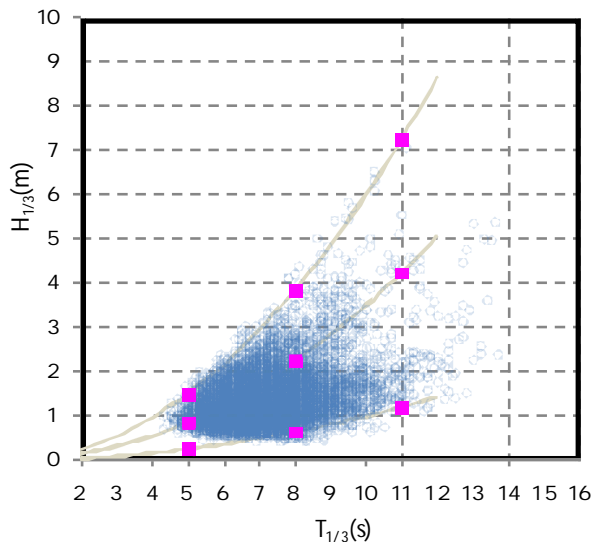

图-8 NOWHAS波浮の波高・周期分布と波浪変形計算条件

表- 2 計算条件

\begin{tabular}{|c|c|}
\hline 計算範囲 & $\begin{array}{l}\text { 13. } 0 \mathrm{~km} x 8.2 \mathrm{~km} \text { (E地形) } \\
\text { 14. } 4 \mathrm{~km} \times 9.5 \mathrm{~km} \text { (S地形) }\end{array}$ \\
\hline 格子サイズ & $20 \mathrm{n} \times 20 \mathrm{~m}$ \\
\hline 波浪条件 & $\begin{array}{c}\text { NOMPHAS波浮の波高・周期分布より9ケース } \\
\text { 波向きはE〜SW代方位 }\end{array}$ \\
\hline 潮位 & HWL. $=+15 \mathrm{~m}$ \\
\hline 計算手法 & エネルギー平衡方程式8) \\
\hline
\end{tabular}
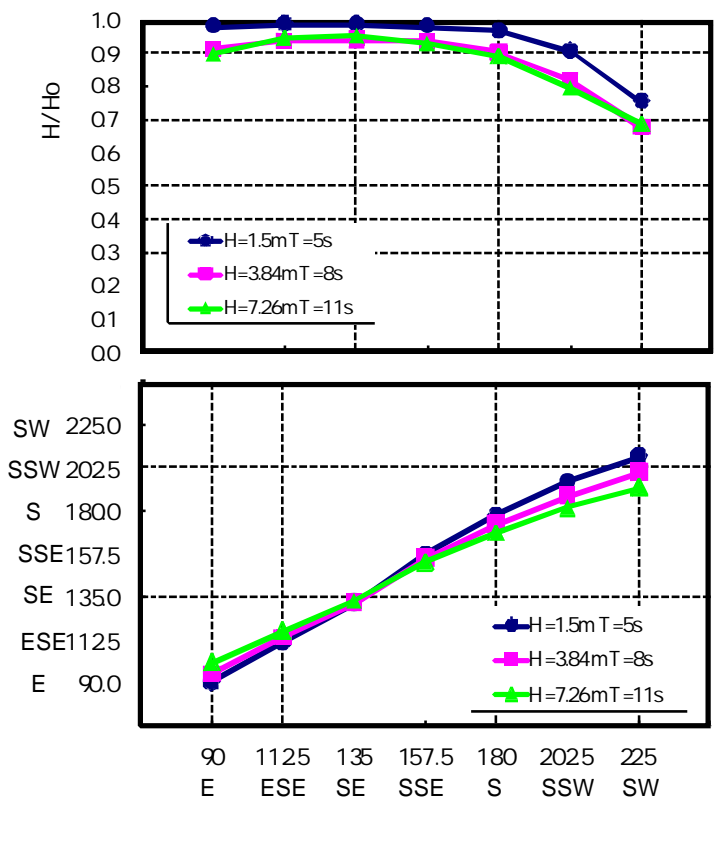

図-9 波浪変形係数 (波浮港)

エネルギー平衡方程式による波浪变形計算を行い，写真 -1に示す防波堤計画位置 (水深20m) の波パワーを推算 した。図-7に波浪変形計算範囲を，表- 亿二計算条件を示 した . 波浪条件のうち沖波条件は，図-8に示すNOWPHS 観測值による波高と周期の相関図から設定した .

波浪変形計算から得られた波浪変形係数を図-9に示し た。防波堤位置では沖波向SからSW来襲波浪が屈折に よりて〜搳減衰することがわかる，光の結果，波浮港防 


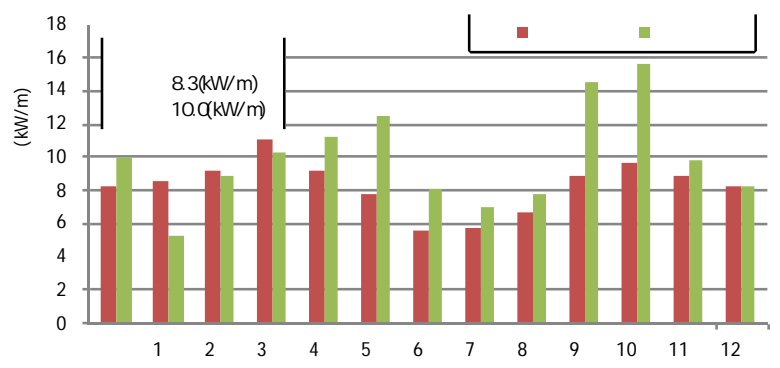

図-10＼cjkstart波浮港と三池港防波堤位置の波パワー

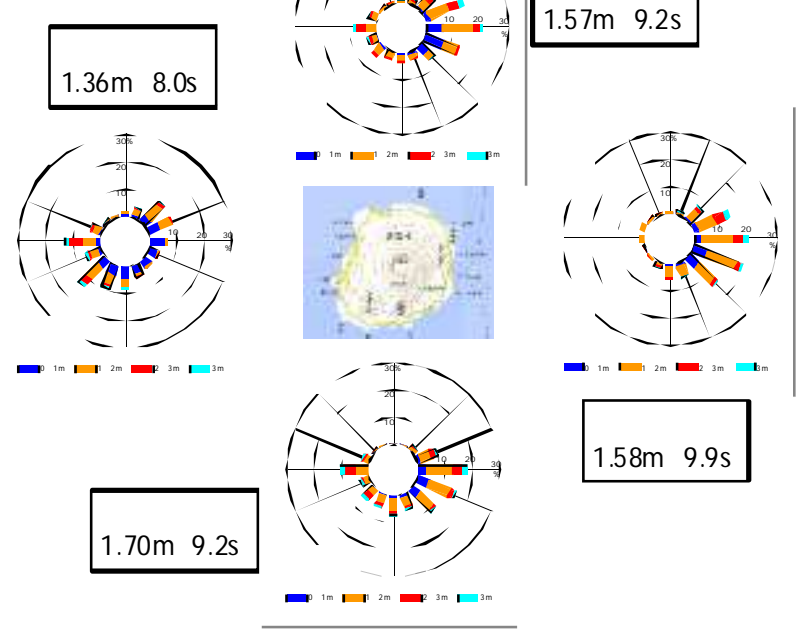

図-11 三宅島周辺の波浪特性 (ONF゙ータ)

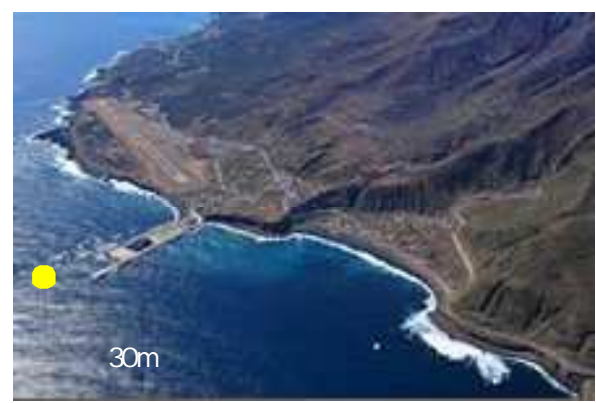

写真 2 三池港の対象位置

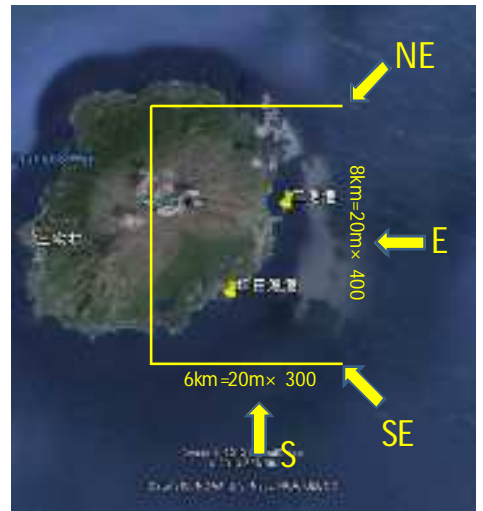

図-12 三池港沖の波浪変形計算範囲

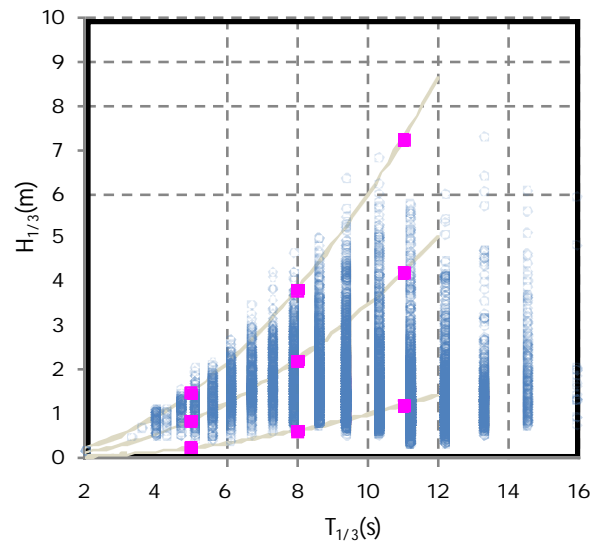

图-13 三宅島東沖OAs波高・周期分布と波浪变形計算条件

表-3 計算条件

\begin{tabular}{|c|c|}
\hline 計算範囲 & 南北8. Okmx 東西6. Okm \\
\hline 格子サイズ & $200 \times 20 m$ \\
\hline 波浪条件 & $\begin{array}{c}\text { 三宅島東沖CWの波高・周期分布より9ケース } \\
\text { 波向きはNE〜Sまで方位 }\end{array}$ \\
\hline 潮位 & HWL. $=+15 \mathrm{~m}$ \\
\hline 計算手法 & エネルギー平衡方程式 \\
\hline
\end{tabular}

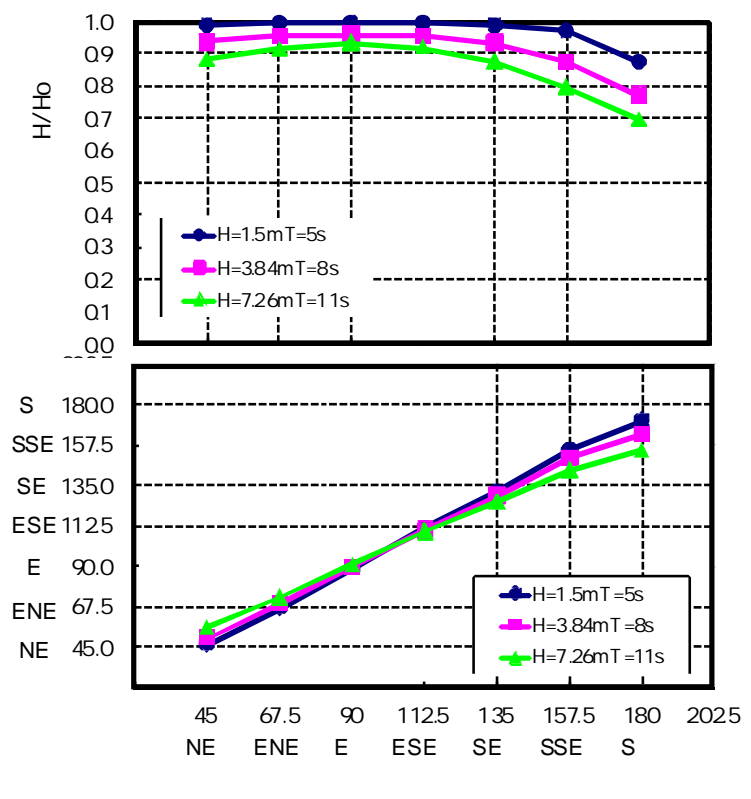

图-14 波浪変形係数 (三池港)

波堤位置の波パワーは8.3( kWh) と推定され，NOPPHS観 測データから算出した波パワー9.9(kWmより割程度小 さくなった (図-10).

\section{(2) 三宅島三池港の波パワー試算}

三池港周辺は波浪観測データがないため，波浪推算デ 一タを基に波パワーの推算を行う. 先ず，三宅島周辺の 波浪特性を把握するため，三宅島周辺のવWだータから 波浪特性を整理した(図-11)。この結果，三宅島周辺で 
は南側の波パワーが高いことが予想される .

次に波浮港と同樣に三池港までの波浪変形計算により 写真-2に示す防波堤計画位置 (水深30m) の波パワーを 推算した . 図-12に波浪変形計算範囲を, 表-3に計算条 件を示した . 波浮港での計算波浪条件と同樣に，沖波条 件は図 13に示す三宅島東沖のCWザータの波高と周期の 相関図から設定した 。

図-14には波浪変形計算結果から得られた波浪変形係 数を示した.三池港防波堤では, 沖波向SEからSの範囲 の来襲波浪が屈折により 2 割減衰することがわかる . また防波堤位置の波パワーとしては10０（kW/m)と推定さ れ，波浮港より割程度大きい波パワーが期待できる結 果となった (図-10)。

\section{4. まとめ}

波力発電の導入指標となる波パワーについて, 波浪観 测データ (NONPHAS) と波浪推算データ (CWM) を用いて 整理を行った . また, 波力発電導入のポテンシャルが高 い離島について, 大島波浮港と三宅島三池港を対象とし た波パワー試算を行った . 弚の結果, 以下のことが明ら かとなった .

(1) 日本全国の波パワー分布をNOWPAS観測データから 整理し, 月別，経年の波パワー変化特性を明らか にした。

(2) 波浪観測のない海域の評価において，波浪推算デー タを用いた評価の精度を確忍した。

（3）大島波浮港と三宅島三池港への波力発電導入を想定
し波パワーを推算し，波浮港 (8.3kWM $)$ より三池 港（10.0kW/m）の方が割程度大きなことを示した．

謝辞 : 本研究は, NPO法人海ロマン21海洋エネルギ一研 究会主催の「離島における海洋エネルギ一研究委員会 : 井上興治主査」での議論力洧益であった . 委員の方に謝 意を表する .

\section{参考文献}

1) 田端竹千穂・柳生忠彦・福田 功：日本沿岸におけ る波のエネルギー, 港湾技術研究所資料, No.364, 20p, 1980.

2) 高橋重雄・安達 崇 : 日本周辺における波パワーの 特性と波力発電, 港湾技術研究所資料, No.654, 18p, 1989.

3) 高橋重雄・安達 崇: 日本周辺における波パワーの 光の利用に関する一考察, 海岸工学論文集, 第 36 巻, pp.874-878, 1989.

4) 永井紀彦・渡邊 弘・川口浩二 : 長期波浪観測に基 づく我国沿岸の波パワー出現特性の検討, 港湾技術研 究所資料, No.895, 26p, 1998.

5) 独立行政法人新エネルギー・産業技術総合開発機 構: 平成 22 年度成果報告書 海洋エネルギーポテン シャルの把握に係る業務 (要約版) , pp.6-19, 2011.

6) 川口浩二・猪股 勉・関 克己・藤木 峻 : 全国港湾海 洋波浪観測年報 (NOWPHAS 2012) , 港湾空港技術研究所 資料, No.1282, 125p, 2014.

7) 永井紀彦：全国港湾海洋波浪観測 30 力年統計 (NOWPHAS 1970-1999)，港湾空港技術研究所資料, No.1035, 388p, 2002.

8) 高山知司・池田直太 ・平石哲也：砕波および反射を 考慮した波浪変形計算, 港湾技術研究所報告, 第 30 巻, 第 1 号, pp21-67, 1991.

\title{
EVALUATION OF WAVE POWER AROUOND JAPAN FOR APPROPRIATE PLACE SELECTION OF WAVE POWER CONVERTER
}

\author{
Hiroyuki KATAYAMA, Haruo YONEYAMA and Ken-ichiro SHIMOSAKO
}

\footnotetext{
Marine Renewable Energy(MRE) is expected after The Great East Japan Earthquake. The consideration for MRE is also progressing and the field test has also begun on the sea. Some types are considered also about wave power converter. It becomes important to predict wave power with high precision for wave power converter.

In this research, the wave power around Japan is rearranged using the wave observation data whose observing point increased. And the local characteristic of wave power is considered. Furthermore, the trial calculation of the wave power was made at the breakwater of the Habu fishing port in the Oshima and the Miike fishing port in the Miyake-jima.
} 